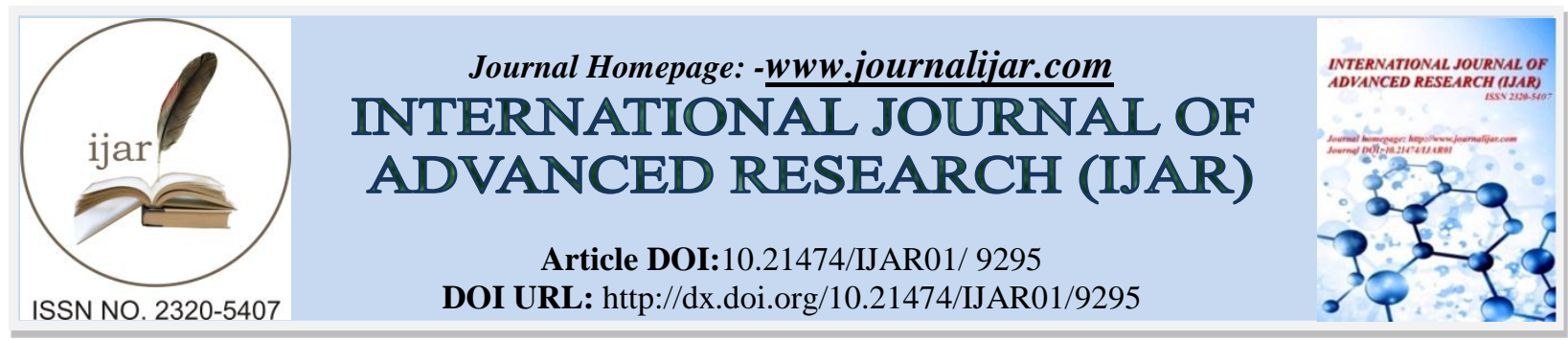

RESEARCH ARTICLE

\title{
STUDY ON THE EFFECTS OF B-GLUCAN AND DRIED CHICORY ROOTS EXTRACT SUPPLEMENTATION IN BROILER DIETS ON IMMUNE SYSTEM, GROWTH AND PERFORMANCE PARAMETERS.
}

\section{Ashraf A. Abd El-Tawab ${ }^{1}$, Ashgan E. Fahmi ${ }^{2}$ And Omnia E. Mohammed ${ }^{3}$.}

1. Bacteriology, Immunology and Mycology Department, Faculty of Veterinary Medicine, Benha University, Egypt.

2. Senior Researcher of immunology department, Animal health research institute, Dokki, Egypt.

3. Veterinarian at animal health research institute lab, Zagazig, Egypt.

\section{Manuscript Info}

Manuscript History

Received: 15 April 2019

Final Accepted: 17 May 2019

Published: June 2019

Key words:-

$\beta$-Glucan, Chicory roots, immune system, performance.

\section{Abstract}

This study was done to investigate the effects of a supplementation of $\beta$-glucan and dried Chicory roots extract into broiler rations on immune system and other parameters like growth performance, intestinal length and serum cholesterol and triglycerides levels. A total of 320 male Ross broiler chicks of one day old were divided into 3groups one of them control and other three are treatment groups, each contain 80 birds. Each group then was further divided into 4 replicate groups of 20 birds in each. The treatment groups were supplemented with $0.7 \%$ dried Chicory roots, $0.015 \% \beta$-glucan and $0.7 \%$ dried chicory roots plus $0.015 \% \beta$-glucan, respectively, and the experiment lasted for 6 weeks. Determining the effects on specific antibody titer for ND virus to investigate some immune-modulatory roles, and for that purpose, administration of ND vaccine on day 10 and then on day 26. In addition, the serum cholesterol and triglyceride levels were investigated. At the end of the experiment, dried Chicory roots supplementation to the diets significantly increased the intestine length. The supplementation of $0.7 \%$ dried Chicory roots with $0.015 \% \beta$ glucan to the diets had negative effects on some performance parameters and also increased serum cholesterol and triglycerides levels $(\mathrm{P}<0.001, \mathrm{P}<0.01$, respectively). The amount of abdominal fat of the broilers in the post mortem examinations also increased during that treatment in the birds in the Chicory roots with $\beta$-glucan group by the end of the trial period.

Copy Right, IJAR, 2019,. All rights reserved.

\section{Introduction:-}

Prebiotics are non- digestible feed additives that can selectively Stimulating the growth and/or increase the specific activation of one or more kinds of bacteria in the digestive system, which then improve the host health (Gibson and Roberfroid, 1995). Non-digestible carbohydrates (oligo and polysaccharides), some peptides, and proteins, and certain lipids work in the colon as potential prebiotics (Young, 1998). Prebiotics reduce bacterial colonization of some bacteria such as E. coli and Salmonella and also increase nonpathogenic microorganisms (Chen, 2003).

Corresponding Author:-Ashraf A. Abd El-Tawab.

Address:-Bacteriology, Immunology and Mycology Department, Faculty of Veterinary Medicine,

Benha University, Egypt. 
Feeding with dried Chicory roots and $\beta$-Glucan has positive effects on broiler performance and abdominal fat percentage (Ammerman et al., 1989), and it had also shown positive effects regarding the egg production of laying hens in other studies (Waldroup et al., 1993; Chen et al., 2005). The studies of Fiordaliso et al. (1995) and Vanhoof and De Schrijver (1995) observed that alimental oligosaccharides have effects on decreasing blood cholesterol levels and reducing plasma triglyceride concentrations.

$\beta$ - Glucan can be used as traditional antimicrobials for poultry (Cheng et al., 2004). $\beta$-glucan may increase some immune reactions depending on studies which show that birds fed with $\beta$-glucan have much larger primary and secondary lymphoid organs, as bursa of Fabricius, the spleen, and thymus so for that $\beta$-glucan can be used as an immune regulator (Guo et al., 2003). Lowry et al. (2005) found that addition of $\beta$-glucan into diets resulted in the decrease of Salmonella enteritidis levels in the liver / spleen from $76 \%$ to $6 \%$ compared to the control. The poultry category needs new products that can enlarge the productivity of rations and protect the birds against the pathogenic effects of intestinal microorganisms.

The aim of this study was to determine the effect of supplementation of $\beta$-glucan, Chicory roots powder, and $\beta$ glucan + Chicory roots added to broiler rations, on some immune and performance parameters [antibody level developed against Newcastle disease (ND), bodyweight gain (BWG), feed conversion ratio (FCR), feed intake (Fiordaliso et al.), yields of some organs (bursa of Fabricius, liver, heart, spleen, abdominal fat), total triglyceride and total cholesterol levels and intestinal lengths. Therefore, our hypothesis for the present study was that the $\beta$ glucan and chicory roots combination could provide rising in the productivity and health levels of broilers.

\section{Materials and Methods:-}

A total of 320 male Ross PM3 of one day old broiler chicks were divided into four groups with 80 birds in each. Each group was subdivided into further 4 groups and each subgroup contained 20 chicks. The control group rations were not supplemented with $\beta$-glucan or chicory roots. The experimental groups received $0.015 \% \beta$-glucan, $0.7 \%$ chicory roots powder and $0.015 \% \beta$-glucan $+0.7 \%$ chicory roots powder, respectively. The amount of wheat was decreased equal to the amount of $\beta$-glucan and chicory roots powder added to the rations.

The products used in this experiment, such as Saccharomyces cerevisiae (Leucogard R), which was extracted from bread yeast (1-3; 1-6 $\beta$-D-glucan), included 29\% $\beta$-glucan (Transfer Point products ,SC 29075, 803-932-2134, USA), dried chicory extract (Blue Lily Organics LLC, Phonix, AZ 85050 . USA), included $>70 \%$ inulin in its dry form. The chicks were fed with starter diets (1-21 days) that contained $3200 \mathrm{kcal} / \mathrm{kg}$ metabolizable energy (Ammerman et al.) and $22.0 \%$ crude protein (CP), grower diets (22-42 days) that contained $3200 \mathrm{kcal} / \mathrm{kg} \mathrm{ME}$ and $19 \%$ CP (Table 1), and water was supplied ad libitum during the 6 week feeding period.

The birds were housed in wire-bottomed pens with electrical heaters during the experimental period. The temperature started at $35^{\circ} \mathrm{C}$ the first week and was gradually reduced according to normal management practice $20^{\circ} \mathrm{C}$ at week 5. The chicks were maintained on a $24 \mathrm{~h}$ constant light schedule till the end of the experiment. Feed and water were presented ad libitum to the birds. Administration of ND vaccine (Hitchner B1, Ceva) on days 10 and 26 was applied. Coccidiostats (Salinomycin sodium; $70 \mathrm{mg} / \mathrm{kg}$ complete feed) were added on days 11, 15, and 21. The study was approved by the Animal health research institute, Cairo and faculty of veterinary medicine Benha University, Egypt.

Feed intake (FI) and body weight (BW) were weekly recorded and FCR could be then calculating by dividing total amount of feed consumed by the BWG of the birds. At the end of the experiment, the birds were individually weighed to determine their body weights. Three birds from each pen were then collected randomly for slaughter. The bursa of Fabricius, heart, spleen, liver, intestine, abdominal fat from each bird were weighed, and then calculate the organ yield of the birds by dividing the abdominal fat by body weight. Intestinal length was also calculated by measuring the length of the small and large intestines. Twenty chicks were slaughtered to determine the maternal antibody level on the first day. On day 26 and before slaughtering (at the end of the experiment), blood was taken from the wing vein from 3 birds from each replication. Serum was kept at $-20{ }^{\circ} \mathrm{C}$. The animals were vaccinated against Newcastle disease (Hitchner B1, Ceva) on days 10 and 26 of the experiment by spraying method. Maternal antibody and specific antibody levels formed against ND were determined using a hemagglutination inhibition test according to Allan and Gough (1974). 
At the end of the experiment blood samples were collected from 3 birds from each group from the wing vein and the serum was separated by centrifugation of the blood. Serum cholesterol and triglyceride were analyzed. Total triglyceride levels were measured spectrophotometrically (GD081500, GLOBE Diagnostics), and total cholesterol was determined in blood using kits (ab65390, abcam Diagnostics, Cambridge, USA). Data were statically analyzed using SPSS 25 for Windows. One-way ANOVA was used to determine the differences among the groups. Differences among treatments means were identified by Duncan's multiple range test (Duncan, 1955). All of the data were expressed as means \pm standard error (Dawson et al., 2004).

\section{Results:-}

In the current study, there was no significant difference between the measured ND-specific antibody titer among the groups (Table 2). Organ weights and their rates to $100 \mathrm{~g}$ body weight showed no significant differences among the groups $(\mathrm{P}>0.05)$ (Table 5). Also no significant differences were observed among the treatments regarding BWG, FI and FCR, and carcass yield (Tables 3 and 4).

There was significant difference among the groups $(\mathrm{P}<0.05)$ in the length of the duodenum. In the Chicory group the total intestinal lengths and longest cecum were measured $(\mathrm{P}<0.001)$ (Table 6). It was found that addition of $\beta$ glucan and chicory roots into the diets resulted in a decrease of serum total cholesterol $(\mathrm{P}<0.001)$ and total triglyceride $(\mathrm{P}<0.01)$ levels (Table 5). After removing the fatty tissues surrounding the abdomen and gizzard it was found that there is no significant differences $(P>0.05)$ between the groups for abdominal fat content of the carcasses.

\section{Discussion:-}

At the end of the experiment, the performance of the broilers was not affected, even with levels of up to $0.015 \% \beta$ glucan, $0.7 \%$ chicory root extract, and $0.015 \% \beta$-glucan $+0.7 \%$ chicory root extract (Table 3), no significant differences were observed between the groups for BWG, FI and FCR. Waldroup et al. (1993) reported that supplementation of $0.375 \% \beta$-glucan in the diet of broilers did not affect growth performance. Chen et al. (2005) observed that there weren't significant effects of chicory roots extract on growth performance in chickens, and However, Van Leeuwen et al. (2006) observed that $1 \%$ and $2 \%$ chicory extract supplementation to broiler rations positively affected BWG, FI, and FCR (P < 0.05). Chen (2003) showed similar results for male broilers fed with chicory extract or oligofructose. Ammerman et al. (1989) reported that after supplementation with oligofructose, body weight gain was increased at day 46. Chen (2003) found that use of oligofructose or chicory roots improved the FCR in broilers. There was no significant effect on the rate of BWG, FI, and FCR when $0.06 \% \beta$-glucan was used (Cheng et al., 2004). However, Chae et al. (2006) study reported that adding more than $0.01 \% \beta$-glucan to broiler rations positively affected BW.

In this study, during the experimental period, the lowest BWG value was obtained with the $\beta$-glucan + chicory roots supplementation. Therefore, it can be concluded that there is a negative interaction between these two supplements. There was no significant difference among the groups for average carcass yield and carcass weight values $(\mathrm{P}>0.05)$ (Table 4). This result was in agreement with the findings of Waldroup et al. (1993). Ammerman et al. (1989) reported that supplementation of oligofructose in broiler diets at a level of $0.375 \%$ showed better carcass yield values. Chen (2003) stated that oligofructose or chicory root extract enhanced carcass weight in broilers. There weren't significant differences in the bursa of Fabricius, liver, spleen, heart, intestinal weights, and abdominal fat and their ratios to $100 \mathrm{~g} \mathrm{BW}$, but some numerical variations were found between the treatment groups $(\mathrm{P}>0.05)$ (Table 6). Abdominal fat weight was decreased by the supplementation of $0.7 \%$ chicory root extract to the ration which is considered to be a loss in carcass value and means that additional energy was spent by the bird. Waldroup et al. (1993) results were in agreement with the findings that the length of the duodenum among the trial groups showed significant differences $(\mathrm{P}<0.05)$ while the length (jejunum + ileum) was not statistically different $(\mathrm{P}>$ 0.05). The longest cecum length was measured in the chicory group $(\mathrm{P}<0.001)$. This outcome was in agreement with the findings of Roberfroid (1993). Chen (2003) found that adding chicory roots extracts to rations increased the length of the intestine in female broilers. Chen et al. (2005) stated that supplementation of $1 \%$ oligofructose and $1 \%$ chicory roots powder in white Leghorn chicken rations increased the length of small and large intestines. In this study, the longest values for total intestinal length (duodenum + jejunum + ileum + cecum) was recorded for $0.7 \%$ chicory roots extracts, followed by $0.015 \% \beta$-glucan (Table 5), the control group, and $0.015 \% \beta$-glucan $+0.7 \%$ chicory roots extracts. According to the above reported values statistically significant differences were found between the control, chicory, and $\beta$-glucan + chicory treatments $(\mathrm{P}<0.05)$. The results of studies showed that the 
more intestinal length is, the better the nutrient absorption will be, and this causes an increase in body weight (Chen, 2003). Some studies support the idea of using prebiotics to increase the length of the intestinal villus, which then affects the length of the intestine, as well Parker (1974) and Sanders (2003). Although the length of intestines increased in the $\beta$-glucan group, there weren't parallel results for the body weight gains. In the present study, as a result of vaccination against the ND-specific antibody titer (Table 2) at the first measurement (day 26), the highest value was determined in the $\beta$-glucan group, followed by the $\beta$-glucan with chicory roots group, the control group, and the chicory root group. At the second measurement (at the end of the experimental period), the highest value was determined in the control group, and there were no significant differences among the groups (Table 2). These results are in agreement with the findings of Cheng et al. (2004). Based on this study, a low $\beta$-glucan supplement level $(0.015 \%)$ may prevent Newcastle disease. An experiment conducted by Cheng et al. (2004). With broilers fed $0.001 \%, 0.013 \%, 0.025 \%$, and $0.04 \% \beta$-glucan for 6 weeks in which the antibody titer against ND viruses was evaluated. At the end of this study, no differences were observed in the antibody levels among the groups. Guo et al. (2003), Lowry et al. (2005) and Huff et al. (2003) suggested that $\beta$-glucan can decrease environmental stress and may support the immunity. Blood serum total cholesterol values were significantly different among the groups. When these values were taken into consideration, the lowest value was found in the chicory roots group ( $\mathrm{P}<0.001)$ (Table 5). When total triglyceride values were taken into consideration, the lowest value was found in the chicory roots group $(\mathrm{P}<0.01)$ (Table 5). It was found that $\beta$-glucan and chicory roots decreased the blood serum total cholesterol and triglyceride levels significantly $(\mathrm{P}<0.001$ and $\mathrm{P}<0.01$, respectively). These results are in agreement with the findings of Chen (2003) who also observed that adding chicory roots extracts to feeds decreased the serum cholesterol level in broilers. Adding $0.7 \%$ chicory roots extracts to broiler rations increased cecum weight and intestinal length compared to the other groups, but decreased the abdominal fat weight. A possible reason for that is the unavailability of the stress condition for producing the effects of $\beta$-glucan and chicory roots extracts on the immune system. For this reason, it may be suggested that they be used to stimulate immunity and increase the preventive effect. During the experiment, one animal from each group died: in the first week, one from the $\beta$-glucan + chicory roots extract group; in the second week, one from the $\beta$-glucan group; and in the third week, one from the $\beta$-glucan group. These results did not statistically affect the results of the experiment. It was concluded that combination of $\beta$-glucan and chicory roots extract is not advisable for broilers. Use of them in combination resulted in an increase in abdominal fat and a decrease in body weight gain. Further studies should be applied to support these results and to explain the mechanism of $\beta$-glucan and chicory roots extract on the effect of broiler performance.

\section{Disclosure Statement}

No competing financial interests exist.

Table 1:-Composition Of The Experimental Diets

\begin{tabular}{|c|c|c|}
\hline & Starter diet (days 1-21) & Grower diet (days 22-42) \\
\hline \multicolumn{3}{|l|}{ Ingredient } \\
\hline Wheat & 4.45 & 4.77 \\
\hline Corn & 42 & 51.85 \\
\hline Soybean meal & 26 & 18.83 \\
\hline Fishmeal & 3 & 2 \\
\hline Vegetable oil & 4 & 2.3 \\
\hline Limestone & 1.5 & 1.5 \\
\hline $\mathrm{DCP}$ & 1.3 & 1.3 \\
\hline $\mathrm{NaCl}$ & 0.25 & 0.25 \\
\hline DL-methionine & 0.25 & 0.15 \\
\hline Mineral* & 0.10 & 0.10 \\
\hline Vitamin $* *$ & 0.15 & 0.15 \\
\hline \multicolumn{3}{|l|}{ Calculated value } \\
\hline $\mathrm{ME}, \mathrm{kcal} / \mathrm{kg}$ & 3200 & 3200 \\
\hline Crude protein, $\%$ & 22 & 19 \\
\hline
\end{tabular}

*Mineral mix supplies per kg diet: $150 \mathrm{mg} \mathrm{Mn,} 14 \mathrm{mg} \mathrm{Cu}, 120 \mathrm{mg} \mathrm{Fe}$, , , $0.4 \mathrm{mg}$ Co, $3 \mathrm{mg} \mathrm{I}$, and $0.3 \mathrm{mg} \mathrm{Se,} 150 \mathrm{mg}$ Zn. **Vitamin mix supplies per kg diet: cholecalciferol, $6000 \mathrm{IU}$; retinol acetate, 21,000 IU; tocopherol acetate, $120 \mathrm{mg}$; menadione, $45 \mathrm{mg}$; thiamin, $4.5 \mathrm{mg} ; 13 \mathrm{mg}$; niacin, $60 \mathrm{mg}$; ribofl avin; pantothenic acid, $19 \mathrm{mg}$; pyridoxine, $8 \mathrm{mg}$; cobalamin, $0.044 \mathrm{mg}$; folic acid, $3 \mathrm{mg}$; ascorbic acid, $76 \mathrm{mg}$ and biotin $0.226 \mathrm{mg}$;. DCP: Dicalcium phosphate 
Table 2:-Antibody Titers For Nd

\begin{tabular}{|c|c|c|c|c|c|}
\hline Control & Control & $\boldsymbol{\beta}$-glucan & Chicory roots & $\begin{array}{c}\boldsymbol{\beta} \text {-glucan } \\
\text { +Chicory } \\
\text { roots }\end{array}$ & P \\
\hline First, day 10 & $5.2 \pm 0.7$ & $5.8 \pm 0.8$ & $4.6 \pm 0.8$ & $5.4 \pm 0.5$ & 0.716 \\
\hline Second, day 26 & $7.3 \pm 0.6$ & $6.6 \pm 0.6$ & $6.6 \pm 0.6$ & $6.7 \pm 0.7$ & 0.907 \\
\hline
\end{tabular}

Maternal $=5.91 \pm 0.22$. Data are presented as mean \pm standard error $(n=12)$.

Table 3:-Influence Of B-Glucan And Chicory Roots Supplementation On The Growth Performance Of The Broilers

\begin{tabular}{|c|c|c|c|c|c|}
\hline & Control & $\beta$-glucan & Chicory roots & $\begin{array}{c}\text { 及-glucan } \\
+ \text { Chicory root }\end{array}$ & $\mathbf{P}$ \\
\hline \multicolumn{6}{|l|}{ 0-3 weeks } \\
\hline FI, g & $1066.8 \pm 23.7$ & $1132.3 \pm 7.4$ & $1080.6 \pm 22.6$ & $1074.1 \pm 43.3$ & 0.348 \\
\hline $\mathrm{BWG}, \mathrm{g}$ & $673.1 \pm 12.3$ & $688.9 \pm 23.1$ & $665.6 \pm 18.2$ & $660.5 \pm 18.5$ & 0.674 \\
\hline $\mathrm{FCR}, \mathrm{kg} / \mathrm{kg}$ & $1.7 \pm 0.2$ & $1.8 \pm 0.2$ & $1.7 \pm 0.2$ & $1.7 \pm 0.2$ & 0.830 \\
\hline \multicolumn{6}{|l|}{ 3-6 weeks } \\
\hline FI, g & $3375.6 \pm 53.2$ & $3455.4 \pm 81.6$ & $3340.5 \pm 120.1$ & $3415.9 \pm 63.7$ & 0.791 \\
\hline $\mathrm{BWG}, \mathrm{g}$ & $1740.1 \pm 18.1$ & $1710.3 \pm 25$ & $1680.1 \pm 26.7$ & $1677.5 \pm 19.1$ & 0.211 \\
\hline $\mathrm{FCR}, \mathrm{kg} / \mathrm{kg}$ & $1.9 \pm 0.1$ & $2.0 \pm 0.1$ & $2.0 \pm 0.1$ & $2.1 \pm 0.1$ & 0.565 \\
\hline \multicolumn{6}{|l|}{ 0-6 weeks } \\
\hline FI, g & $4440.5 \pm 58.8$ & $4585.5 \pm 87.6$ & $4420.2 \pm 128.6$ & $4486.1 \pm 84.2$ & 0.607 \\
\hline $\mathrm{BWG}, \mathrm{g}$ & $2407.9 \pm 12.1$ & $2395.0 \pm 44.9$ & $2340.5 \pm 37.3$ & $2335.1 \pm 29.5$ & 0.312 \\
\hline $\mathrm{FCR}, \mathrm{kg} / \mathrm{kg}$ & $1.8 \pm 0.1$ & $1.9 \pm 0.1$ & $1.9 \pm 0.1$ & $1.9 \pm 0.1$ & 0.511 \\
\hline
\end{tabular}

Data are presented as mean \pm standard error $(n=3), F I=$ feed intake, $B W G=$ body weight gain, $\mathrm{FCR}=$ feed conversion ratio

Table 4:-Average Carcass Rate And Carcass Yield Of Groups

\begin{tabular}{|c|c|c|c|c|c|}
\hline & Control & $\beta$-glucan & Chicory roots & $\begin{array}{c}\beta \text {-glucan } \\
+ \text { Chicory root }\end{array}$ & $\mathbf{P}$ \\
\hline BW, g & $2505.2 \pm 45.1$ & $2436.9 \pm 52.9$ & $2417.2 \pm 47.9$ & $2380.5 \pm 48.9$ & 0.345 \\
\hline $\mathrm{HCW}, \mathrm{g}$ & $1865.3 \pm 40.6$ & $1793.5 \pm 40.9$ & $1787.8 \pm 39.1$ & $1756.8 \pm 38.9$ & 0.269 \\
\hline $\mathrm{HCP}, \%$ & $74.7 \pm 0.4$ & $73.9 \pm 0.4$ & $74.5 \pm 0.4$ & $74.1 \pm 1.0$ & 0.816 \\
\hline
\end{tabular}

$\mathrm{BW}=$ body weight, $\mathrm{HCP}=$ hot carcass percentage, $\mathrm{HCW}=$ hot carcass weight, Data are presented as mean \pm standard error $(n=12)$

Table 5:-Total Serum Cholesterol And Triglyceride Levels

\begin{tabular}{|l|c|c|c|c|c|}
\hline & Control & $\beta$-glucan & Chicory roots & $\boldsymbol{\beta}$-glucan + Chicory root & P \\
\hline TC, $\mathrm{mg} / \mathrm{dL}$ & $122.0 \pm 4.85 \mathrm{a}$ & $118.2 \pm 2.8 \mathrm{a}$ & $114.4 \pm 2.3 \mathrm{a}$ & $135.5 \pm 3.7 \mathrm{~b}$ & $0.000 * * *$ \\
\hline TTG, $\mathrm{mg} / \mathrm{dL}$ & $33.6 \pm 1.3 \mathrm{ab}$ & $29.4 \pm 1.0 \mathrm{ab}$ & $26.1 \pm 1.0 \mathrm{a}$ & $35.0 \pm 1.8 \mathrm{~b}$ & $0.002^{* *}$ \\
\hline
\end{tabular}

$\mathrm{TC}=$ total cholesterol, TTG $=$ total triglyceride. Data are presented as mean \pm standard error $(\mathrm{n}=12)$, Abc Means in a row with different superscripts differ significantly. $* * \mathrm{P}<0.01$ and $* * * \mathrm{P}<0.001$

Table 6:-Evaluated Bursa Of Fabricius, Liver, Spleen, Heart, Intestine Weights, Abdominal Fat, And Their Ratios To $100 \mathrm{G} \mathrm{Bwg}$

\begin{tabular}{|c|c|c|c|c|c|}
\hline & Control & $\beta$-glucan & $\begin{array}{c}\text { Chicory } \\
\text { roots }\end{array}$ & $\begin{array}{c}\beta \text {-glucan }+ \\
\text { Chicory root }\end{array}$ & $\mathbf{P}$ \\
\hline BF weight & $5.3 \pm 0.3$ & $4.7 \pm 0.3$ & $4.6 \pm 0.3$ & $5.3 \pm 0.3$ & 0.172 \\
\hline Liver weight, $g$ & $53.6 \pm 1.8$ & $52.3 \pm 1.8$ & $50.6 \pm 1.6$ & $50.2 \pm 1.3$ & 0.425 \\
\hline Spleen weight, $\mathrm{g}$ & $4.6 \pm 0.2$ & $4.6 \pm 0.3$ & $4.2 \pm 0.3$ & $4.1 \pm 0.3$ & 0.413 \\
\hline Heart weight, $g$ & $13.8 \pm 0.5$ & $13.8 \pm 0.6$ & $13.2 \pm 0.6$ & $14.3 \pm 0.6$ & 0.597 \\
\hline Intestine weight, $\mathrm{g}$ & $69.2 \pm 2.3$ & $64.2 \pm 2.1$ & $65.4 \pm 1.6$ & $60.8 \pm 2.1$ & 0.052 \\
\hline Abdominal fat weight, $g$ & $37.6 \pm 4.5$ & $34.5 \pm 2.9$ & $30.8 \pm 2.0$ & $41.8 \pm 2.5$ & 0.097 \\
\hline
\end{tabular}




\begin{tabular}{|l|c|c|c|c|c|}
\hline Liver ratio, g/100 g BW & $2.1 \pm 0.1$ & $2.1 \pm 0.1$ & $2.1 \pm 0.1$ & $2.1 \pm 0.1$ & 0.846 \\
\hline Spleen ratio, g/100 g BW & $0.21 \pm 0.1$ & $0.21 \pm 0.1$ & $0.21 \pm 0.1$ & $0.21 \pm 0.1$ & 0.626 \\
\hline Heart ratio, g/100 g BW & $0.61 \pm 0.1$ & $0.61 \pm 0.1$ & $0.61 \pm 0.1$ & $0.61 \pm 0.1$ & 0.303 \\
\hline BF ratio, g/100 g BW & $0.21 \pm 0.1$ & $0.21 \pm 0.1$ & $0.21 \pm 0.1$ & $0.21 \pm 0.1$ & 0.304 \\
\hline $\begin{array}{l}\text { Intestine ratio, g/100 g } \\
\text { BW }\end{array}$ & $2.9 \pm 0.1$ & $2.8 \pm 0.1$ & $2.8 \pm 0.1$ & $2.7 \pm 0.1$ & 0.503 \\
\hline $\begin{array}{l}\text { Abdominal fat ratio, } \\
\text { g/100 g BW }\end{array}$ & $1.6 \pm 0.2$ & $1.5 \pm 0.1$ & $1.4 \pm 0.1$ & $1.9 \pm 0.1$ & 0.073 \\
\hline Small intestine, cm & $151.0 \pm 5.1$ & $156.3 \pm 3.8$ & $159.1 \pm 2.8$ & $150.8 \pm 4.8$ & 0.426 \\
\hline Duodenum, cm & $31.7 \pm 1.5 \mathrm{~b}$ & $30.7 \pm 0.7 \mathrm{ab}$ & $30.7 \pm 0.6 \mathrm{~b}$ & $28.9 \pm 0.7 \mathrm{a}$ & $0.043^{*}$ \\
\hline Cecum, cm & $36.3 \pm 1.7 \mathrm{a}$ & $38.4 \pm 1.6 \mathrm{a}$ & $48.5 \pm 2.0 \mathrm{~b}$ & $38.5 \pm 1.2 \mathrm{a}$ & $0.000^{* * *}$ \\
\hline Total intestine length, cm & $217.9 \pm 6.2 \mathrm{a}$ & $224.2 \pm 4.8 \mathrm{ab}$ & $237.3 \pm 3.1 \mathrm{~b}$ & $216.2 \pm 5.7 \mathrm{a}$ & $0.021^{*}$ \\
\hline
\end{tabular}

$\mathrm{BF}=$ bursa of Fabricius, BW = body weight. Data are presented as mean \pm standard error $(\mathrm{n}=12)$, Abc Means in a row with different superscripts differ significantly. $* \mathrm{P}<0.05, * * * \mathrm{P}<0.001$

\section{References:-}

1. Allan, W. and R. Gough (1974): A standard haemagglutination inhibition test for Newcastle disease.(1). A comparison of macro and micro methods. Veterinary Record, 95(6): 120-123.

2. Ammerman, E., C. Quarles and P. Twining (1989): Evaluation of fructooligosaccharides on performance and carcass yield of male broilers. Poult. Sci, 68(Suppl 1): 167.

3. Chae, B., J. Lohakare, W. Moon, S. Lee, Y. Park and T.-W. Hahn (2006): Effects of supplementation of $\beta$ glucan on the growth performance and immunity in broilers. Research in veterinary science, 80(3): 291-298.

4. Chen, T. (2003): Effect of adding chicory fructans in feed on broiler growth performance, serum cholesterol and intestinal length. in Proceedings of the Int. J. Poult. Sci.

5. Chen, Y., C. Nakthong and T. Chen (2005): Improvement of laying hen performance by dietary prebiotic chicory oligofructose and inulin. International Journal of Poultry Science, 4(2): 103-108.

6. Cheng, Y.-H., D.-N. Lee, C.-M. Wen and C.-F. Weng (2004): Effects of $\beta$-glucan supplementation on lymphocyte proliferation, macrophage chemotaxis and specific immune responses in broilers. Asianaustralasian journal of animal sciences, 17(8): 1145-1149.

7. Dawson, B., R.G. Trapp and A. Greive (2004): Basic \& clinical biostatistics, Lange Medical Books/McGrawHill New York.

8. Duncan, D.B. (1955): Multiple range and multiple F tests. Biometrics, 11(1): 1-42.

9. Fiordaliso, M., N. Kok, J.P. Desager, F. Goethals, D. Deboyser, M. Roberfroid and N. Delzenne (1995): Dietary oligofructose lowers triglycerides, phospholipids and cholesterol in serum and very low density lipoproteins of rats. Lipids, 30(2): 163-167.

10. Gibson, G.R. and M.B. Roberfroid (1995): Dietary modulation of the human colonic microbiota: introducing the concept of prebiotics. The Journal of nutrition, 125(6): 1401-1412.

11. Guo, Y., R. Ali and M. Qureshi (2003): The influence of $\beta$-glucan on immune responses in broiler chicks. Immunopharmacology and immunotoxicology, 25(3): 461-472.

12. Huff, G., W. Huff, N. Rath, J. Balog and G. Tellez (2003): Immunomodulation With B-1, 3/1, 6-Glucan (Immustim $®)$ Affects Growth Performance And Resistance To Escherichia Coli Respiratory Infection Of Broiler Chickens. Poultry Science, 8257.

13. Lowry, V., M. Farnell, P. Ferro, C. Swaggerty, A. Bahl and M. Kogut (2005): Purified $\beta$-glucan as an abiotic feed additive up-regulates the innate immune response in immature chickens against Salmonella enterica serovar Enteritidis. International journal of food microbiology, 98(3): 309-318.

14. Parker, R. (1974): Probiotics, the other half of the antibiotic story. Anim Nutr Health, 294-8.

15. Roberfroid, M. (1993): Dietary fiber, inulin, and oligofructose: a review comparing their physiological effects. Critical Reviews in Food Science \& Nutrition, 33(2): 103-148.

16. Sanders, M.E. (2003): Probiotics: considerations for human health. Nutrition reviews, 61(3): 91-99.

17. Van Leeuwen, P., J. Verdonk, J. Van Der Klis and J. Van Loo (2006): Inulins (chicory fructans) improve performance of young broilers. in Proceedings of the XII European Poultry Conference (EPC), Verona, Italy, September, p. 10-14.

18. Vanhoof, K. and R. De Schrijver (1995): Effect of unprocessed and baked inulin on lipid metabolism in normoand hypercholesterolemic rats. Nutrition research, 15(11): 1637-1646. 
19. Waldroup, A., J. Skinner, R. Hierholzer and P. Waldroup (1993): An evaluation of fructooligosaccharide in diets for broiler chickens and effects on salmonellae contamination of carcasses. Poultry Science, 72(4): 643650.

20. Young, J. (1998): European market developments in prebiotic-and probiotic-containing foodstuffs. British Journal of Nutrition, 80(S2): S231-S233. 